TITLE:

\title{
Principal Fourier component of motion stimulus dominates the initial optokinetic response in mice(Abstract_要旨)
}

\section{AUTHOR(S):}

Sugita, Yuko

\section{CITATION:}

Sugita, Yuko. Principal Fourier component of motion stimulus dominates the initial optokinetic response in mice. 京都大学, 2013, 博士(医科学)

ISSUE DATE:

2013-03-25

URL:

http://hdl.handle.net/2433/174825

RIGHT: 


\begin{tabular}{|l|l|c|c|}
\hline 京都大学 & 博士 ( 医科学 ） & 氏 名 & \multicolumn{1}{|c|}{ 杉田 祐子 } \\
\hline 論文題目 & $\begin{array}{l}\text { Principal Fourier component of motion stimulus dominates the initial optokinetic } \\
\text { response in mice } \\
\text { (マウス視運動性応答初期相は視覚刺激の最大フーリエ要素の影響を強く受ける) }\end{array}$ \\
\hline
\end{tabular}

(論文内容の要旨)

視運動性応答 OKR （Optokinetic response）は、広い視野の視覚刺激が一様に持続的に動 くときに誘発される眼球運動である。ヒトをはじめとする霊長類では、大脳皮質、第一次 視覚野 (V1)、高次視覚野(MT, MST 野)を経由する皮質系と、大脳皮質を経由しない皮質 下系の 2 種類の経路が OKR に関与寸ることが知られている。皮質下系経路では、網膜か ら入力された視覚情報は副視索系、視索核を経由し、前庭神経核、外眼筋運動神経核へと 伝わると考えられている。大脳皮質が発達していないウサギやマウスではこの皮質下系経 路の久が OKR 発現に関与し、網膜内の神経回路で視覚刺激の動きが検出されることが知 られている。

本研究では、OKRに関する視覚情報処理のうち、視覚運動の検出機構に注目した。視 覚運動の検出機構は、主に 2 種類あることが知られている。一つは、視覚パターンの全体とし ての動きを検出する機構、もう一つは視覚刺激の中の空間周波数要素の動きを検出する機構 である。霊長類におけるOKRに関する2つの経路のうち皮質系経路では、後者の検出機構が 働いていることが明らかになっている。しかし、皮質下系経路での視覚運動検出がどちらの機 構によるかは明らかになっていない。そこで、マウスの OKRの基盤となる視覚運動の検出機構 を調べるため、マウスの右眼の前方置いた CRT 上に視覚刺激を呈示し、右眼の眼球運動をビ デオ方式で計測し、視覚刺激によって誘発されるOKRの初期相に注目して解析を行った。 まず、方形波縞からその基本周波数の正弦波を引き算して構成された mf (missing fundamental) 刺激を視覚刺激しして使用した。この視覚パターンは様々な周波数要素で構成さ れており、 $\mathrm{mf}$ 刺激を $1 / 4$ 周期動か儿た時には、パターンを構成する要素のうち最も振幅(コント ラスト卜)の大きい要素(3f 要素)は全体の動きとは逆方向に動としいら特徽がある。CRT 上に呈示 した視覚パターン( $\mathrm{mf}$ 刺激)を左方向に動か寸と、視覚パターンとは逆向きのOKRが誘発され た。その OKR の大きさは $3 \mathrm{f}$ 要素と同じ空間周波数とコントラストを持つ正弦波刺激(3f 刺激)に 対する反応とほぼ一致していた。

次に、視覚刺激を構成する複数の要素の動きが OKR にどのように影響するかを調べるため に、 $\mathrm{mf}$ 刺激を構成する要素のうち $3 \mathrm{f}$ 要素、 $5 \mathrm{f}$ 要素の 2 つ要素の重和合わせで作られる3f5f 刺激を用いて実験を行った。3f5f 刺激を $1 / 4$ 周期ずつ移動させると $3 f$ 要素はパターンの移動 方向とは逆方向に動き、5f 要素は同方向に動 。呈示寸る $3 f 5 f$ 刺激を構成寸る要素のうち、3f 要素のコントラストは 20\%に固定し、 $5 f$ 要素のコントラストを $3 f$ 要素のコントラストの $1 / 4$ 倍から 4 倍まで変えた。その結果、一方の要素のコントラストがもう一方の要素のコントラストの 2 倍以上 の時は、コントラストの小さいほうの要素は OKR にほとんど寄与しないことがわかった。

$\mathrm{mf}$ 刺激で眼が視覚パターンの動く方向とは逆方向、つまり視覚パターンに含まれる 1 番大きい周波数要素の方向に動くという結果は、マウスの OKR の視覚運動検出機構 はパターン全体としての動きを検出するよりはむしろ視覚刺激を周波数要素に分けて 処理していることを示している。さらに3f5f 刺激の実験からは、マウスの OKR の発現 の際には、視覚刺激を周波数要素に分解し、処理するメカニズムに加えて、反対の運 動方向に選択性を持つ運動検出機構が互いに抑制するメカニズム（相互抑制）が視覚 情報処理系で働いている可能性があることが示唆された。
（論文審査の結果の要旨）

視運動性応答 OKR（Optokinetic response）は、広い視野の視覚刺激が一様に持続的に 動くときに誘発される眼球運動である。

マウスの OKR の基盤となる視覚運動の検出機構を明らかにするため、OKR の初期相 に注目し眼球運動を計測した。

視覚刺激として、矩形波縞からその基本周波数の正弦波を引いた mf（missing fundamental) 縞を使用した。この視覚パターンは様々な周波数要素で構成されており、1/4周期 ごとに動かすと、視覚パターンを構成する要素のうち最も大きい要素は、パターンの動く方向と 逆向きに動くといら特徴がある。CRT 上に呈示した視覚パターン(mf 縞)を耳から鼻方向に動か すと、視覚パターンとは逆向き(鼻から耳方向)のOKRが誘発された。眼が視覚パターンの動 方向とは逆、つまり、視覚パターンに含まれる最大要素の方向に動くというこの結果は、マウス OKR の視覚運動検出機構は視覚刺激を要素に分けて処理しているといらことを示している。 次に各要素の動きの影響を調べるため、mf 縞を構成する成分のうち、3f 成分、5f 成分の 2 つの要素で作られる3f5f 縞を用いて実験を行った。その結果、OKR にはコントラストのより大き い要素の影響が強く現れることがわかった。

以上の研究は、マウス OKR のための視覚運動検出機構を明らかにしたもので、視覚情報処 理機構の解明に寄与するところが多い。

したがって、本論文は博士(医科学)の学位論文として価值のあるものと認める。

なお、本学位授与申請者は、平成 24 年 11 月 30 日実施の論文内容とそれに関連した試問を 受け、合格と認められたものである。 